\title{
International money supply and real estate risk premium - The case of the London office market.
}

\author{
Alain Coën ${ }^{\mathrm{a}}$, Benoit Lefebvre ${ }^{\mathrm{b}, *}$, Arnaud Simon ${ }^{\mathrm{b}}$ \\ ${ }^{a}$ University of Quebec in Montreal, Department of Finance \\ ${ }^{b}$ Paris Dauphine University, DRM Finance
}

\begin{abstract}
The main purpose of this study is to deeply investigate the determinants of the risk premium for the Central London office market between Q2-2002 and Q3-2015 using a vector autoregression model. We shed new light on the role of central banks in the commercial real estate risk premium. Indeed, since the global financial crisis (GFC), central banks have used unconventional monetary policies, increasing the quantity of money available in the economy and creating structural changes. To pick up the relation between real estate and the money supply, we have constructed a monetary index adapted to the office market. We find that throughout the whole period [2002 to 2015], the vacancy rate, the employment in services, the FTSE 100, the new monetary index and the autoregressive parameter are the main determinants of the historical risk premium. However, this result hides the complex realities of different sub-periods. Finally, we study the structural changes introduced by the monetary policy using a structural VAR modeling and impulse-response functions.
\end{abstract}

JEL Classification: C30, E50, R30.

Keywords: real estate, direct office market, risk premium, monetary policies, structural VAR

*Corresponding author

Email addresses: coen.alain@uqam.ca (Alain Coën), benoit.lefebvre@dauphine.fr (Benoit Lefebvre), arnaud.simon@dauphine.fr (Arnaud Simon)

Preprint submitted to Journal of International Money and Finance

May 30, 2017 


\section{Introduction}

Our aim in this study is to analyse the dynamics of the direct Central London office market risk premium and its most relevant determinants from 2002 to 2015, giving special attention to the monetary supply. Although the Central London office market is one of the most analysed office markets in the real estate economics literature, as reported by Hendershott, Lizieri and MacGregor (2010), our understanding of its mechanism is still fragmented and requires deeper investigation. Since the early 80s, this office market has been growing, and its stock value can be estimated at approximately 270 billion in pounds sterling. According to the Global Financial Centers Index, London was the first financial centre in 2016, before New York and far ahead of its main competitors in Europe (Zürich: 9th rank; Frankfurt: 19th rank). This market is, indeed, characterized by two main topics: globalization and finance. Since the nineteenth century, London has been qualified as a global city with a growing importance in terms of international financial services, especially since the mid-80s and the so-called "Big bang". According to Sassen (2001) (reported in Lecomte 2012), a global city is "a strategic site for the management of the global economy and the production of the most advanced services and financial operations", and the London office market satisfies these conditions. As an illustration, and according to TheCityUK, London is the first OTC market for derivatives, the first exchange rates market (with a volume of $37 \%$ of world transactions in 2016: more than the added volumes of New York and Tokyo). London is also in second place for asset management and in first place for foreign investors. The LSE reports the highest number of cross-listed firms, and the insurance industry sector is the first in Europe and second in the world. According to Hendershott, Lizieri and MacGregor (2010), financial employment represented $73 \%$ of total employment in the City of London in 2006. It is informative to link this percentage with the statistic reported by Lizieri (2009), who observed that more than $85 \%$ of real estate space in the City was occupied by financial and professional services at the same date. One of the main drawbacks of the Central London office market is the availability of data and its high volatility. Real estate research is often driven by the availability of data. However, we were able to use a private and exclusive database that describes the occupier and the investment market in London.

A growing literature has been devoted to the London office market modelling. The main determinants and potential risk factors may be reported. Wheaton, Torto and Evans (1997) highlight the importance of the role employment plays in the cyclicality of the office market. Hendershott, Lizieri and Matysiak (1999) report the relative importance of employment and interest rate fluctuations. Similarly, Hendershott, MacGregor and Tse (2002) confirm the crucial role of employment. Rent dynamics are also a point of interest - for instance, with Hendershott et al. (2009). Lizieri (2009) developed a model in which employment, interest rates and inflation can explain the level of rents in the London City office market. Moreover, some authors shed light on the persistence of real estate cycles, such as Wheaton et al. (1997), Farelly and Sanderson (2005), Hendershott et al. (2009) and Lizieri (2009) among others. The recent article by Lizieri and Pain (2014) should also be mentioned. Analysing the relationship between the production of financial space and systemic risk, they 
highlighted the crucial role of the London City office market in the diffusion process during the GFC.

The global determinants of office returns have been largely analysed in the real estate economics literature, as reported by Sivitanidou and Sivitanides (1999), Hendershott et al. (1999), De Wit and Van Dijk (2003) and Hendershott and MacGregor (2005), among others. These articles underline the fact that the supply and demand relationships are related to variables such as construction, absorption, vacancy rate, rents, employment growth and real interest rates. However, these variables are acknowledged to exhibit endogeneity biases. In this context, there is a need to use a robust econometric method that includes simultaneous equations: the seminal VAR modeling introduced by Sims (1980) is a good candidate.

As it has been well acknowledged, the 2002-2015 period has been marked by the unprecedented Global Financial Crisis (hereafter GFC), and important volatility in the monetary market. As reported by Ramey (2016), a significant effort in the macroeconomics literature has been made over the last 30 years to identify the causal effects of monetary policy on economic activity. For instance, several studies showed that real estate investment trusts (REITs) followed the same pattern as other financial assets regarding monetary policy rate changes (Johnson 2000, Bredin, O'Reilly and Stevenson 2007, 2011 among others). However, since 2009 monetary policies became unconventional. The effects of central banks on financial markets are now purely related to quantitative easing (QE; a synonym for an expansionary monetary policy), and their impact on the direct real estate market has not been well acknowledged or documented yet. The effects of monetary shocks, defined as an unanticipated deviation in a central bank's policy (Campbell, Evans, Fisher and Justiniano (2012) and Nakamura and Sternson (2015)), may be relevantly analysed within a Structural Vector Autoregression (SVAR) framework, as suggested by Barsky and Sims (2011), Francis et al. (2014) and Ben Zeev and Khan (2015).

Our methodological contribution is threefold. First, in order to take into account the international dimension of the London office market and its evolutions, we introduce and compute a dynamic specific composite monetary index. Second, in order to analyse the potential determinant candidate of the direct office risk premium dynamic, we suggest the use of VAR modeling. Third, we recommend the use of a structural VAR model to highlight the potential contribution of the index during a volatile and crisis period, marked by relevant breaking points in the monetary policy.

At first sight, the monetary index and the rates series appear to offer significant explanations of the London premium throughout the period [2002 to 2015], but this hides a very different reality. Indeed, before the GFC, neither the rates nor the index are significant (on that basis, the period 2002 to 2008 could be qualified as a bubble period). During the GFC and after 2009, on the other hand, our monetary index is strongly significant, but the rates are not. During the QE period, the office market reacted to the monetary policies through an upward adjustment of prices. The structural model exhibits the same kind of results when we consider an unexpected monetary shock on the economy. Office prices face a more important adjustment during an unexpected monetary shock than during a shock on rates. The paper proceeds as follows. Section 2 explains how we extend the previous literature on the subject. Section 3 is devoted to the methodology and to the presentation of the data. 
Section 4 presents the empirical results that show the relevance of our dynamic composite monetary index. Section 5 concludes.

\section{International real estate investments - some facts and the monetary index}

\subsection{Real Estate Risk Premium}

Basically, the real estate risk premium is defined as the difference between the property total return and a non-risky asset (usually the national 10-year bond). The total return is divided into two components: the income return and the capital growth. The first is the net income received by the owner, expressed as a percentage of the invested capital.

$$
\text { Income Return }=\frac{\mathrm{N}_{\mathrm{t}}}{\mathrm{CV}_{\mathrm{t}-1}}
$$

The capital growth is the percentage of variation between the capital value at the end of the period and the amount originally invested.

$$
\text { Capital Growth }=\frac{\mathrm{CV}_{\mathrm{t}}}{\mathrm{CV}_{\mathrm{t}-1}}-1
$$

Thus:

$$
\text { Total Return }=\frac{\mathrm{N}_{\mathrm{t}}}{\mathrm{CV}_{\mathrm{t}-1}}+\frac{\mathrm{CV}_{\mathrm{t}}}{\mathrm{CV}_{\mathrm{t}-1}}-1,
$$

with $\mathrm{N}_{\mathrm{t}}$ the net income received at time $t$, and $C \mathrm{~V}_{\mathrm{t}}$ the capital value at time $\mathrm{t}$.

In the professional literature, it may happen that the risk premium is reduced to the yield gap; that is a simple difference between the income return and the risk-free rate, omitting the capital growth. This simplification is problematic because, according to historical values, the total return is mainly directed by the capital growth (Figure 1).

During the first cycle (from 1987 to 1993), the capital value jumped during the first three years, creating a bubble on the market. When the investment volumes dropped due to global uncertainties, prices collapsed, causing a negative total return during three years. The second real estate cycle ended in 2002 with a crisis on the occupier market due to the dot-com crash. Following the crisis and the collapse of major companies, the vacancy rate in London jumped from $4 \%$ to $12.3 \%$, and the capital value decreased. After 2004 , the market experienced three years of record highs with huge amounts of being money invested, strong demand, high prices and high rent prices. With the subprime crisis, the "prime" capital value dropped from 2007 to 2009 by 42\%. ${ }^{1}$ However, as we can see in Figure 1, despite the global economic downturn, the capital return and the total return were strongly negative just for one year and before quickly recovering. Trying to reduce the effect of the GFC, central banks decided to adopt non-conventional monetary policies. The question of

\footnotetext{
${ }^{1}$ The "prime" capital value is the price per square meter for an office unit of standard size, of the highest quality and specification and in the best location of the market.
} 
the consequences of the QE programs on the real estate market deserves to be analysed. Indeed, the market in London reached a historical peak in 2016 at 49272 euros per square meter.

\section{[INSERT FIGURE 1]}

\subsection{Real Estate and monetary aggregates: some stylized facts}

In the recent economic history, the impact of the monetary policies on the real estate market is an issue. For instance, Taylor (2007) indicates that there is a link between the Federal Reserve System's adoption of an accommodative policy between 2002 and 2004 and a housing bubble in the US. ${ }^{2}$ Even if the monetary policy of the Bank of England was not as accommodative as the Fed during that period, we can suspect that the US monetary excesses had an impact on the UK financial market because of the cross-border investments. Moreover, since 2009, we saw the rise of non-conventional monetary policies (interest rates close to zero, QE, etc.), that created a great amount of money on the financial markets.

Money supply is defined as the total amount of monetary assets and other liquid instruments circulating in a country at a particular time. However, due to the great variety of investors on the market in London, we cannot restrict our analysis to the national monetary policy. It is a key point that the nationality of the investors in that market evolve across time (Figure $2)$.

\section{[INSERT FIGURE 2]}

During the first period, from 2004 to 2006, national investment was the main driver (almost $60 \%$ of the total investment). After 2007, the percentage of foreign investors strongly increased. From 2010, national investments represented only 35\% of the total investment, and the share of the Eurozone investors was just half as large as it was before the crisis. Before 2007, Irish investors were the most important foreign investors on the London market. However, due to the economic downturn, the share of Ireland almost felt to zero, decreasing the total contribution of the Eurozone. ${ }^{3}$

The national withdrawal is explained by the emergence of new investors. The shares of Middle Eastern and of East Asian investors sharply increased after the economic crisis. Some countries such as China and Qatar started to invest in this market while others (Singapore or Kuwait for example) amplified their positions. The London market is now driven by overseas investors. On that basis, just using the local monetary aggregates would imply a

\footnotetext{
${ }^{2}$ Taylor [2007] computes a theoretical interest rate based on inflation and GDP and shows that the actual interest rate was below the theoretical one and that there were monetary excesses.

${ }^{3}$ Fiscal incentives may explain this point.
} 
loss of information. It is necessary to find an appropriate measure of the global monetary policies to correctly take into account the situation in London. As countries have different definitions of broad money, a simple sum of monetary aggregates would under-represent countries that have narrow definitions of $\mathrm{M} 2 .^{4}$

\subsection{A monetary index for international real estate investments}

The aim of the monetary index is to study the effect of the international money supply on the London office market using an appropriate aggregation. Beyer, Doornik and Hendry (2001) developed an aggregation method to reconstruct historical data of the Eurozone for the monetary aggregate M3, GDP and prices over two decades. Thereafter, this method has been widely used in previous literature (Giese and Tuxen 2008 and Belke, Orth and Setzer 2010) in order to aggregate data - such as GDP, monetary stocks and interest rates - using national series. Starting from this methodology, we adapted it for international real estate investments. It has three stages.

- Calculating the weight of the investment volume in commercial real estate according to the nationality of the investor.

- Computing the growth rates of M2 lags of k periods, measured in local currency.

- Aggregating the growth rate using the weight of the first step.

More formally, we have:

$$
\mathrm{MI}_{\mathrm{t}}=100 \prod_{\mathrm{t}=1}^{\mathrm{T}}\left[1+\sum_{\mathrm{t}=1}^{\mathrm{T}}\left(\frac{\operatorname{Inv}_{\mathrm{n}, \mathrm{t}}}{\sum_{\mathrm{n}=1}^{\mathrm{N}} \operatorname{Inv}_{\mathrm{n}, \mathrm{t}}}\right) \times\left(\frac{\mathrm{M} 2_{\mathrm{n}, \mathrm{t}-\mathrm{k}} \times \mathrm{e}_{\mathrm{t}-\mathrm{k}}}{\mathrm{M} 2_{\mathrm{n}, \mathrm{t}-\mathrm{k}-1} \times \mathrm{e}_{\mathrm{t}-\mathrm{k}-1}}-1\right)\right],
$$

where $\operatorname{Inv}_{n, t}$ is the invested volume from a country $n$ at time $t, M 2_{n, t}$ is the monetary aggregate of the country $n, k$ is a time lag, and $e_{t}$ is the exchange rate.

We consider that the investment volume at the period $t$ is defined by the money supply of the period, lagged by several periods, due to the real estate illiquidity and the length of the investment process (between 3.5 and 5 months, according to Devaney and Scofield (2014), omitting the period between the change in monetary policy and the investment decision). The illiquid aspect of commercial real estate has been well documented by Geltner et al. (2001). ${ }^{5}$ The real estate supply is inelastic and does not respond contemporaneously to the demand; the space cannot be quickly reduced (or increased) in case of a drop (or hike) in demand.

Moreover, to determine the real investment capacity of foreign investors on the London office market, the monetary stock should be expressed in local currency.

\footnotetext{
${ }^{4} \mathrm{M} 2$ is a money aggregate that measures the money supply. This is generally the sum of currency and coins, demand deposits, money markets and savings deposits.

${ }^{5}$ Geltner et al. (2007) developed a kinked supply function in which supply is inelastic until rents are equal to the replacement costs.
} 


\section{Model and Data}

\subsection{VAR model}

To model the risk premium, we will first use a vector autoregression model. A VAR(p) with $\mathrm{k}$ endogenous variables is a system of $\mathrm{k}$ equations of identical structure with $\mathrm{p}$ lags. The vector autoregressive model will allow the study of the statistical relationship between variables. The large set of available variables implies that we need to realize an appropriate selection before estimating the office risk premium. The choice is based on previous literature and also on the multicollinearity issue.

For the sectorial variables, we will just retain the vacancy rate and the "prime" rental value. The vacancy rate is the ratio between the immediately available supply and the existing stock. It is a proxy for market liquidity and for the risk faced by the investors (D'Argensio and Laurin 2009). The "prime" rent is the top headline rent for an office unit of standard size but of the highest quality and specifications and in the best location within its market. For the economic variables, we choose the London workforce jobs in services and the FTSE 100 closing price. The first variable is a key factor for the Greater London economic activities, mainly based on the financial services. It has already been widely used as a proxy for the space demand in the office market (De Wit and Van Dijk 2003). The FTSE 100 is a proxy of the activity in the UK at a larger scale. Moreover, as financial industries are very important in London, this factor should matter. These companies are indeed the renters of the offices (Sivitadinou and Sivitadines 1999).

More formally, the first VAR equation that we will run is:

$$
\begin{aligned}
& \Delta \mathrm{RP}_{\mathrm{t}}=\beta_{0}+\beta_{1} \Delta \mathrm{RP}_{\mathrm{t}-1}+\beta_{2} \Delta \ln \left(\mathrm{PR}_{\mathrm{t}-1}\right)+\beta_{3} \Delta \ln \left(\mathrm{EM}_{\mathrm{t}-1}\right)+ \\
& \beta_{4} \Delta \ln \left(\mathrm{FTSE}_{\mathrm{t}-1}\right)+\beta_{5} \Delta \ln \left(\mathrm{VR}_{\mathrm{t}-1}\right)+\epsilon_{\mathrm{t}},
\end{aligned}
$$

where $\Delta$ denotes the first difference operator, $\beta_{0}$ is a constant, $\mathrm{RP}_{\mathrm{t}}$ refers to the risk premium of the London market at time $t, \mathrm{PR}_{\mathrm{t}}$ refers to the prime rent, $\mathrm{EM}_{\mathrm{t}}$ refers to the employment in services, FTSE $_{t}$ refers to the closing price of the FTSE 100 and $\mathrm{VR}_{\mathrm{t}}$ refers to the vacancy rate.

The risk premium is computed using appraisal values and the 10-year UK government bond. The literature thoroughly documents the fact that appraisers use past market values to estimate current offices valuations, underestimating price volatility (Firstenberg, Ross and Zisler 1988; Quan and Quigley 1989, 1991 and Drouhin and Simon 2014). This is called the "tyranny of past values": appraisers use the sales comparison method for the valuation of an asset, introducing some autocorrelation in their indices. Indeed, in the case of a market downturn, appraisers do not immediately include the price drop in their estimations. A reasonable method for capturing this smoothing issue is the use an autoregressive model (Geltner 1989 and Brown and Matysiak 1998).

After estimating this initial equation, we will add the monetary index $\mathrm{MI}_{\mathrm{t}}$ to determine the effect of the monetary policies on the risk premium for different periods. As an alternative measure, we will also test the interbank rate (LIBOR). 


$$
\begin{aligned}
\Delta \mathrm{RP}_{\mathrm{t}}=\beta_{0}+\beta_{1} \Delta \mathrm{RP}_{\mathrm{t}-1}+\beta_{2} \Delta \ln \left(\mathrm{PR}_{\mathrm{t}-1}\right)+\beta_{3} \Delta \ln \left(\mathrm{EM}_{\mathrm{t}-1}\right)+ \\
\beta_{4} \Delta \ln \left(\mathrm{FTSE}_{\mathrm{t}-1}\right)+\beta_{5} \Delta \ln \left(\mathrm{VR}_{\mathrm{t}-1}\right)+\beta_{6} \Delta \ln \left(\mathrm{MI}_{\mathrm{t}-1}\right)+\epsilon_{\mathrm{t}}
\end{aligned}
$$

However, the Bai and Perron test $(1998,2003)$, when applied to the monetary index, indicates that there are structural breakpoints. ${ }^{6}$ The results show five structural breaks between 2002-Q2 and 2015-Q3 (Figure 3). These dates (2005-Q3, 2007-Q3, 2009-Q3, 2011Q3 and 2013-Q4) can be interpreted in relation with main monetary events. The first structural break in 2005-Q3 can be related to the tightening of the major central banks monetary policies. Indeed, the US policy rate was below its theoretical rate from 2002 until the end of 2005 (Taylor 2007), creating an excess of liquidity on the market. The second structural change is related to the subprime crisis that started in mid-2007 in the US. Finally, in 2009-Q3, 2011-Q3 and 2013-Q4, the structural breaks could be implied by quantitative easing programs and the launch of three waves of large-scale assets purchases by the Fed and by the Bank of England since December 2008.

\section{[INSERT FIGURE 3]}

\subsection{Structural VAR}

In a similar situation with structural changes, a structural VAR is more appropriate. It allows for controlling these changes and also for imposing conditions on the coefficients based on economic theory.

A structural VAR can be written as:

$$
\mathrm{Ay}_{\mathrm{t}}=\mathrm{A}_{1}^{*} \mathrm{y}_{\mathrm{t}}+\cdots+\mathrm{A}_{p}^{*} \mathrm{y}_{\mathrm{t}-\mathrm{p}}+\mathrm{B} \epsilon_{\mathrm{t}}
$$

where $\mathrm{y}_{\mathrm{t}}$ is a vector of variables and $\epsilon_{\mathrm{t}}$ are unanticipated shocks.

The idea consists of imposing some restriction on the reduced form model using the A matrix. ${ }^{7}$ The restrictions had to be consistent with the economic argument (Blanchard and Quah 1989). We suggest the following relationship among the variables (zeros above the matrix are suppressed):

$$
\operatorname{Ay}_{\mathrm{t}}=\left[\begin{array}{cccccc}
1 & & & & & \\
\beta_{21} & 1 & & & & \\
\beta_{31} & \beta_{32} & 1 & & & \\
0 & 0 & \beta_{43} & 1 & & \\
0 & \beta_{52} & 0 & \beta_{54} & 1 & \\
\beta_{61} & \beta_{62} & \beta_{63} & \beta_{64} & \beta_{65} & 1
\end{array}\right]\left[\begin{array}{c}
\mathrm{I}_{\mathrm{t}} \\
\mathrm{FTSE}_{\mathrm{t}} \\
\mathrm{EM}_{\mathrm{t}} \\
\mathrm{VR}_{\mathrm{t}} \\
\mathrm{PR}_{\mathrm{t}} \\
\mathrm{RP}_{\mathrm{t}}
\end{array}\right]
$$

\footnotetext{
${ }^{6}$ We have estimated a simple regression model with only one constant regressor, and we used a multiple break-point test (Bai and Perron 2003).

${ }^{7}$ Note that if (where is the identity matrix), the coefficient matrix will not differ from the ones obtained with the VAR.
} 
We assume that the first two variables are exogenous and are not determined by the sectorial variables of the model. We consider that the closing price of the FTSE 100 can depend on the monetary index due to the close relationship between the available money and the stock market. Employment can depend on both the monetary index and the UK stock market index, reflecting that levels of employment can depend on financial activity, especially for London. It is straightforward to consider the vacancy rate as depending on the employment level and that the "prime" rent is supposed to adjust to both the employment level and the FTSE 100. Indeed, the biggest firms want to pay for the prime rent. Finally, the risk premium depends contemporaneously on all the variables in the system.

Once the relations are estimated, it is possible to generate impulse response functions (IRFs), which describe how the model reacts to a shock.

After an exogenous shock on the variable $i$ that occurs at time $t$, the impulse response function of variable $\mathrm{j}$ at time $\mathrm{t}+\mathrm{h}$ is:

$$
\frac{\delta \mathrm{y}_{\mathrm{j}, \mathrm{t}+\mathrm{h}}}{\delta \epsilon_{\mathrm{i}, \mathrm{t}}}=\mathrm{C}_{\mathrm{j}, \mathrm{h}}
$$

The value $\mathrm{C}_{\mathrm{j}, \mathrm{h}}$ represents the consequences of an unanticipated shock, defined as a unit increase in $\epsilon_{\mathrm{t}}$ on each variable $\mathrm{j}$ at a given date $(\mathrm{t}+\mathrm{h})$.

\subsection{Data}

The database we use is unique and includes three types of quarterly variables for the period ranging from 2002 Q1 to 2015 Q3. The first type of data is provided by BNP Paribas Real Estate and includes real estate variables on the London market. We have a huge amount of private data on the London office market, and we also know the nationality of the real estate investors. The second type is related to property performance variables retrieved from MSCI (Morgan Stanley Capital International), which include investment returns for the London office market. Finally, we use a set of macroeconomic data provided by the Central Banks for the monetary aggregates, the London Stock Exchange for data on the FTSE 100 and the National Office of Statistics for employment in services data.

\section{[INSERT TABLE 1]}

Table 1 presents the main descriptive statistics. The standard deviations are reasonable compared to the average values. The most volatile variables are, as expected, the real estate risk premium and the FTSE 100 closing price, which both have extreme values and high standard deviations. The risk premium also has a negative skewness and a positive kurtosis, meaning that the series is influenced more by negative shocks and that there is a higher probability of extreme values. Sectorial variables exhibit smaller standard deviations compared to their respective averages, showing the inelasticity of the real estate market. 


\section{Empirical Results}

In this section, we first discuss the VAR results for the whole period and for the various sub-periods. Then, we substitute the monetary index by the LIBOR to determine which series is the most informative for the risk premium. Does it respond more to the rates or to the monetary aggregates? In the last subsection, we consider structural models with the SVAR approach.

The study period [2002-Q2; 2015-Q3] is first decomposed in three parts. [2002-Q2; 2006Q4] corresponds to the pre-GFC period. We will see that it could be qualified as a bubble period for the London office market. The second period, [2007-Q1; 2010-Q1], corresponds to the GFC, while the third one, [2009-Q1; 2015-Q3], is characterized by non-conventional monetary policies along with massive liquidity injections into the economies. ${ }^{8}$ As we can see, the second interval intersects the third one. It is motivated by two reasons; to get enough observations to estimate the model on the various sub-periods, and because it is acceptable to consider that GFC still had effects during the year 2009. In section 4.3, another segmentation into two intervals is analysed. The first interval is [2002-Q2; 2008-Q4], which corresponds to the time period without any QE measures. The second is [2009Q1; 2015Q3], with the QE (the Fed launched its program in December 2008).

\subsection{Optimal lag of the monetary index}

When we have introduced the monetary index (section 2.3), we consider that, due to the illiquidity of the market, the investment volume at a given period is defined by the money supply lagged by several periods. The length of the investment process may differ according to the market, the investor's nationality and the market state. Indeed, London is one of the most liquid real estate markets, and its transaction times should be shorter than in an illiquid market. Moreover, the local nature of the asset implies that transactions with nondomestic investors should take longer time than those with domestic investors. Finally, the market state is also important. When the market is booming, the time needed to transact should be shorter than when the market is in a downturn or in a recovery. Thus, the optimal lag between investment volume and the monetary supply should be statistically determined. To select the optimal lag using statistical inference, we need to estimate a model with all possible lags. Then, we should utilize critical expertise using our knowledge of the market. According to our results, two indexes are significant (Appendix B): the index with one lag and the index with three lags. However, the two indexes have opposite signs. From a real estate point of view, the monetary index should have a positive sign. Indeed, as we will see in more detail, an increase of the money supply available in the market should imply an increase in the investment volume and thus in the premium. Moreover, the model using the index lagged by three periods has greater explanatory power.

Thus, the investment volume should be defined by the monetary variation lagged by three quarters. This result is rather consistent with the average transaction time in the London market.

\footnotetext{
${ }^{8}$ The Fed launched its QE program in December 2008, followed by the Bank of England during the first quarter of 2009 and finally the ECB during the first quarter of 2015.
} 


\subsection{Results for the whole period: relevance of the monetary index}

For the whole period of [2002-Q2; 2015-Q3], all variables are significant, except for the prime rent. The autoregressive parameter is highly significant. This momentum is well known in real estate and commonly explained by two factors. As transactions take time (between 1 and 2 quarters for the London office market), real estate markets are quite slow to respond to a shock; hence, their price-discovering function is affected by inertia. The second explanation is related to the variable of interest itself. The MSCI index is indeed based on appraisal values, and as we saw before, appraisers are submitted to the past values tyranny, which introduces temporal autocorrelation in appraisers' valuations and thus into the index. The value of the autoregressive parameter is around 0.70 , corresponding to the upper bound referenced in the literature. This suggests a great confidence of the appraisers in the recent information (Brown and Matysiak 1998 and Geltner et al. 2007).

The prime rent is not significant for the whole period or on any sub-period. A rent increase implies an increase in the income return but also a decrease in capital growth. Consequently, the global effect of a rent increase on the total return is generally small or null. However, this variable is also a way to control for quality effects, so we use it in the VAR model. An increase in building quality tends to induce an increase of the "prime" rent. However, as we can see, the quality evolutions measured by the "prime" rent did not matter during that period.

\section{[INSERT TABLE 2]}

Employment level had a negative impact. An increase in employment implies an increase of the occupied space. This risk reduction lowers the premium for the investors and is also a sign of economic growth. De Wit and Van Dijk (2003) obtained similar results - specifically a negative relationship between the employment level and real estate returns due to reduced uncertainty.

The FTSE 100 has a positive sign. Indeed, it is also possible to consider that the economy is pursuing a growth path, which positively affects the employment level and thus real estate prices. This effect would be amplified for London, given the city's specialization in the financial industry.

The results for vacancy rate are as expected (Ho et al. 2015). It has a positive effect on the risk premium: when the vacancy rate increases, the risk becomes higher and the premium required by investors also increases. An increase in the vacancy rate suggests a decrease in the income return; competition for space between renters becomes less intense, and the building prices decrease.

Finally, we examine the effect of the monetary index on the premium. The estimate is significant and positive. It is difficult to consider the risk as being reinforced if the quantity of money available is greater. Consequently, it has to be interpreted as a price effect: if the money supply increases, then real estate prices become inflated, which has a positive effect on the capital growth. Moreover, due to a massive purchase of long-term government securities 
by central banks, the quantitative easing implies downward pressure on the government bond yields. Thus, on the one hand, the real estate capital growth increases, and on the other hand, the risk-free rate decreases. The combination of the two phenomena increases the spread; in other words, the premium becomes higher. This index seems to be suitable to study the effects of money supply on the real estate dynamics. The significance is strong, and the adjusted $\mathrm{R}^{2}$ is $5 \%$ higher compared to the model without the index. In the next section, we deepen the analysis to better understand the link between money supply and real estate dynamics as well as how it varies according to the context.

\subsection{Results for the sub-periods: the GFC as a potential breakdown.}

The estimates for the three sub-periods exhibit strong differences. For the first period, all variables become non-significant - even the autoregressive parameter - and the adjusted $\mathrm{R}^{2}$ is also much lower. This result is puzzling and important. The question of whether this period was a bubble can be asked. Indeed, the premium required by investors was not related to important variables in the office market such as the employment level or the vacancy rate. In other words, the premium paid to the investors was not related to market fundamentals. Even the autoregressive parameter was not significant and was smaller than in the other periods, suggesting that the appraisers did not have a great confidence in their valuations. This time interval is characterized by the low rate environment of the post-Internet crisis (dot.com bubble). It is also the period from which subprime loans originated. Taylor (2008) already indicated that evidence of a bubble can be found for the housing market in the United States. Our results for the London office market go in the same direction.

Surprisingly, the results for the sectorial variables recovered their coherency during the GFC. The autoregressive parameter is significant, there is no quality or prime rent effect and the vacancy rate positively impacts the risk premium. Regarding the global variables, neither employment nor the UK financial indexes are significant. Interestingly, when the monetary index is included, the FTSE100 becomes significant with the expected sign. Also, the LIBOR series does not produce such an effect. Thus, the monetary index maintains its explanatory power of the premium during the GFC's turmoil. Furthermore, national investments no longer represented a majority of the investments (Figure 2). Foreign investors, and their respective monetary supplies, have started to lead the London office market.

The third period is related to QE policies, mainly in the US and UK. The autoregressive parameter is significant but not the prime rent. Vacancy rate, which traditionally represents one of the most important risks in a real estate investment, is no longer significant, which may be a surprising result. Employment has no impact, whereas FTSE has a positive effect on the premium. This suggests there is a direct link between the monetary index and the QE policy. The office market reacts to the monetary policies through the adjustment of the premium, more precisely through an upward adjustment of the prices. During the QE period, monetary policies seemed to produce effects on prices and on some of the fundamentals that drive the market (here, the vacancy rate). 


\subsection{How do real estate markets react differently to money supply and the 3-month Libor rate?}

In the last fifteen years, the main tool of monetary policies shifted from short rates to QE, at around Q1-2009. We estimate the model on the corresponding sub-periods of [Q2 2002; Q4 2008] and [Q1 2009; Q3 2015]. For this new segmentation, we compare the explaining power of the monetary index and that of the rate series, substituting one with the other in the model (equation 4).

Both series are statistically significant throughout the whole period. However, if we consider the three sub-periods of the segmentation (cf. section 4.3), the risk-free rate loses its explanatory power at all the sub-intervals, whereas the index keeps its statistical significance for several sub-periods. Also, except for the bubble period of [Q2 2002; Q4 2006], the model with the monetary index seems more relevant and exhibits greater explanatory power. In other words, the unconventional monetary policies would more strongly influence investment decisions in real estate than policies driven by the rates, and the main influence would be price increases.

To better understand the effects of the shift in the policies from conventional to unconventional, we use a new time period ranging from 2002-Q2 to 2008-Q4, as mentioned above. The monetary index is not significant before the quantitative easing, but it becomes strongly significant thereafter, whereas the risk-free rate stays insignificant for both. The model using the interbank rate has slightly better explanatory power for the period before unconventional monetary policies. Before the QE, the market was driven by national investors and by debt: investors were looking for speculative investments with high leveraged returns. Since the crisis, the market has become more driven by equity, and investors are looking for long-term income with a buy-and-hold strategy.

These results highlight the fact that the London office market became significantly sensitive to the monetary supply in the last years. The unconventional monetary policies launched by central banks amplified the effect of monetary supply.

\subsection{Responses to an unexpected monetary shock}

Figure 4 illustrates the effects of a positive shock of one standard deviation of the monetary index on each variable. We obtained interpretations in terms of percentage changes by dividing the responses of the variables by the standard deviation of the index.

After the shock, the monetary index returned to its equilibrium. A $1 \%$ shock on the monetary index generates a peak of $0.2 \%$ for the FTSE 100 closing price during the second period. The effect of employment services level was negative and reached its maximum magnitude at the second period. Regarding the sectorial variables, the shock had a positive effect on the vacancy rate but a negative one on the prime rental value. Regarding the risk premium, there was a negative effect at first; then, the risk premium reaches a peak at the third period. With a $1 \%$ rise in the monetary index, the risk premium is peaking at quarter three at approximately $0.3 \%$. As previously mentioned, it is mostly a price effect. Interestingly, the premium was negative during the first period; the price adjustment was not immediate. 


\section{[INSERT FIGURE 4]}

Restricting the model to the quantitative easing sub-period produces different results for the financial variables (Appendix $\mathrm{C}$ ). The effect of an unexpected shock on the monetary index implies a greater increase in the FTSE $100(0.3 \%)$ and in the office risk premium $(0.4 \%)$, which illustrates the effect of quantitative easing on the office market. This is mostly a price effect: a monetary shock implies an increase in the office prices.

The same model is used to study the effect of a conventional monetary policy based on rates by replacing the monetary index with the 3-month Libor for the full period (Appendix D). A shock in the interbank rate implies a negative response of the financial market index due to the tightening of monetary policy. As the interest rate increases, the total investment decreases, encouraging employment. The effect on the vacancy rate arises from the positive effect on employment along with an increase of the occupied space. As expected, the prime rent has the opposite reaction as the vacancy rate. Finally, a 1\% change in the rate leads to a maximum decrease of $0.15 \%$ in the office risk premium. The results are stronger when using the monetary index compared to interest rates; unconventional monetary policies have a greater effect.

\section{Conclusion}

We have used a vector autoregression model to investigate the determinants of the office risk premium for the Central London market. One of the main objectives is to obtain a better understanding of an elusive concept. The goal is also to determine and to discuss the role of central banks in the historical risk premium and to document the potential effects created by the unconventional monetary policies in recent years.

As expected, we find that, for the whole period, the autoregressive parameter, the vacancy rate and the closing price of the FTSE 100 were significant and had a positive effect on the risk premium, while employment level had a negative impact. Introducing a monetary index based on the nationality of the investors suggests that the global money supply had a significant positive impact on the historical office risk premium. The index allows the international characteristics of the London office market and the inertia of the real estate market to be dealt with. Studying the same model for sub-periods helps to create a clearer understanding of the drivers of the historical risk premium. During the bubble period (2002-2006), the policy of low rates implied a disconnection between real estate markets and their fundamentals. During the quantitative easing period (2009-2015), the office market reacted with upward pressure on prices, implying an increase in the historical premium. If the fundamentals recovered their role after 2009, however, it is important from an urban perspective that the vacancy rate - the main risk for real estate investors - is no longer statistically significant. Finally, a structural VAR was used to study the effect of unexpected monetary policy changes. The results indicate that the response of the risk premium is more important following a shock in the money supply than a shock in the interbank rate. This finding sheds light on the link between monetary policy and commercial real estate, while suggesting future research avenues. 


\section{References}

[1] Bai, J., AND Perron, P. Estimating and testing linear models with multiple structural changes. Econometrica 66, 1 (1998), 47-78.

[2] BAi, J., And Perron, P. Computation and analysis of multiple structural change models. Journal of Applied Econometrics 18, 1 (2003), 1-22.

[3] Barsky, R. B., And Sims, E. R. News shocks and business cycles. Journal of Monetary Economics 58,3 (2011), 273-289.

[4] Belke, A., Orth, W., And Setzer, R. Liquidity and the dynamic pattern of asset price adjustment: A global view. Journal of Banking \& Finance 34, 8 (2010), 1933-1945.

[5] Ben Zeev, N., And Khan, H. Investment-Specific News Shocks and US Business Cycles. Journal of Money, Credit and Banking 47, 7 (2015), 1443-1464.

[6] Beyer, A., Doornik, J. A., And Hendry, D. F. Constructing Historical Euro-zone Data. The Economic Journal 111, 469 (2001), 102-121.

[7] Blanchard, O. J., And Quah, D. The Dynamic Effects of Aggregate Demand and Supply Disturbances. American Economic Review 79, 4 (September 1989), 655-673.

[8] Bredin, D., O’Reilly, G., And Stevenson, S. Monetary shocks and REIT returns. The Journal of Real Estate Finance and Economics 35, 3 (2007), 315-331.

[9] Bredin, D., O’Reilly, G., And Stevenson, S. Monetary policy transmission and real estate investment trusts. International Journal of Finance \& Economics 16, 1 (2011), 92-102.

[10] Brown, G. R., And Matysiak, G. A. Valuation smoothing without temporal aggregation. Journal of Property Research 15, 2 (1998), 89-103.

[11] Campbell, J. R., Evans, C. L., Fisher, J. D., and Justiniano, A. Macroeconomic effects of Federal Reserve forward guidance. Brookings Papers on Economic Activity, 1 (2012), 1-80.

[12] D'Argensio, J.-J., And LAurin, F. The real estate risk premium: A developed/emerging country panel data analysis. The Journal of Portfolio Management 35, 5 (2009), 118-132.

[13] De Wit, I., And VAn Dijk, R. The global determinants of direct office real estate returns. The Journal of Real Estate Finance and Economics 26, 1 (2003), 27-45.

[14] Devaney, S., And Scofield, D. Time to transact: measurement and drivers. In Investment Property Forum, September (2014).

[15] Drouhin, P. A., And Simon, A. Are property derivatives a leading indicator of the real estate market? Journal of European Real Estate Research 7, 2 (2014), 158-180.

[16] Farrelly, K., And Sanderson, B. Modelling regime shifts in the city of London office rental cycle. Journal of Property Research 22 (2005), 325-344.

[17] Firstenberg, P. M., Ross, S. A., And Zisler, R. C. Real estate: the whole story. The Journal of Portfolio Management 14, 3 (1988), 22-34.

[18] Geltner, D. Estimating real estate's systematic risk from aggregate level appraisal-based returns. Real Estate Economics 17, 4 (1989), 463-481.

[19] Geltner, D., Miller, N. G., Clayton, J., and Eichholtz, P. Commercial real estate analysis and investments, 2nd ed., vol. 1. South-western Cincinnati, OH, 2007.

[20] Giese, J. V., And Tuxen, C. K. Global Liquidity, Asset Prices and Monetary Policy: Evidence from Cointegrated VAR Models. Nuffield College, University of Oxford, and Department of Economics, Copenhagen University (2007).

[21] Hendershott, P. H., Lizieri, C. M., and MacGregor, B. D. Asymmetric adjustment in the city of London office market. The Journal of Real Estate Finance and Economics 41, 1 (2010), 80-101.

[22] Hendershott, P. H., Lizieri, C. M., And Matysiak, G. A. The workings of the London office market. Real Estate Economics 27, 2 (1999), 365-387.

[23] Hendershott, P. H., And MacGregor, B. D. Investor rationality: evidence from UK property capitalization rates. Real Estate Economics 33, 2 (2005), 299-322.

[24] Hendershott, P. H., MacGregor, B. D., And Tse, R. Y. Estimation of the rental adjustment process. Real Estate Economics 30, 2 (2002), 165-183. 
[25] Ho, D. K. H., Addae-Dapaah, K., and Glascock, J. L. International Direct Real Estate Risk Premiums in a Multi-Factor Estimation Model. The Journal of Real Estate Finance and Economics 51, 1 (2015), 52-85.

[26] Johnson, R. R. Monetary policy and real estate returns. Journal of Economics and Finance 24, 3 (2000), 283-293.

[27] Lecomte, P. Produits dérivés et actifs immobiliers: étude de faisabilité des méthodes de couverture factorielle. PhD thesis, Paris 10, 2012.

[28] LIZIERI, C. Towers of capital: office markets $E_{3}$ international financial services. Wiley-Blackwell, 2009.

[29] Lizieri, C., AND PAin, K. International office investment in global cities: the production of financial space and systemic risk. Regional Studies 48, 3 (2014), 439-455.

[30] Nakamura, E., And Steinsson, J. High frequency identification of monetary non-neutrality: The information effect. Tech. rep., National Bureau of Economic Research, 2013.

[31] Quan, D. C., AND Quigley, J. M. Inferring an investment return series for real estate from observations on sales. Real Estate Economics 17, 2 (1989), 218-230.

[32] Quan, D. C., AND Quigley, J. M. Price formation and the appraisal function in real estate markets. The Journal of Real Estate Finance and Economics 4, 2 (1991), 127-146.

[33] Ramey, V. A. Macroeconomic shocks and their propagation. Handbook of Macroeconomics 2 (2016), $71-162$.

[34] Sassen, S. The Global City: New York, London, Tokyo. Princeton University Press, 2001.

[35] Sims, C. A. Macroeconomics and reality. Econometrica 48, 1 (1980), 1-48.

[36] Sivitanidou, R., And Sivitanides, P. Office capitalization rates: Real estate and capital market influences. The Journal of Real Estate Finance and Economics 18, 3 (1999), 297-322.

[37] TAYLOR, J. B. Housing and monetary policy. Tech. rep., National Bureau of Economic Research, 2007.

[38] Wheaton, W. C., Torto, R. G., and Evans, P. The cyclic behavior of the Greater London office market. The Journal of Real Estate Finance and Economics 15, 1 (1997), 77-92. 
Figure 1. Decomposition of the historical total return in Central London: 1981-2015.

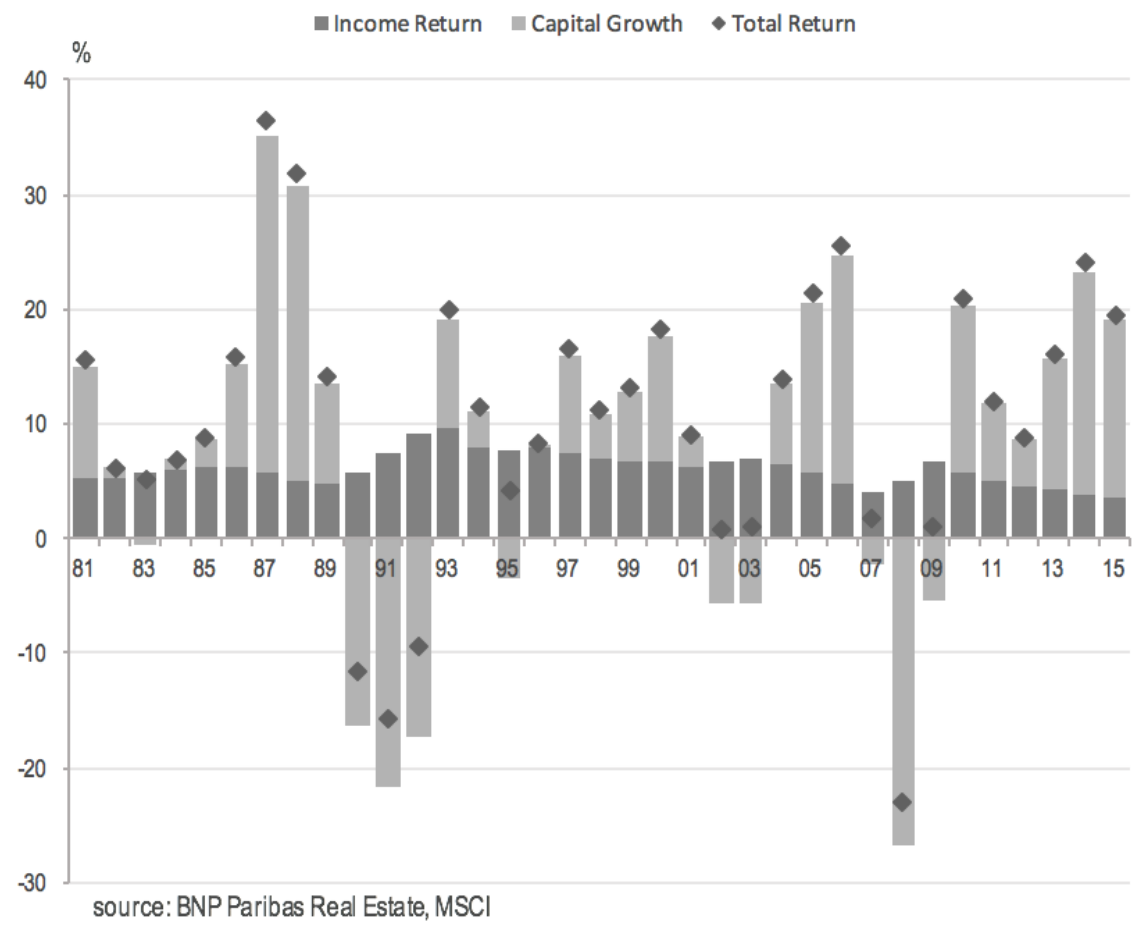

Notes: The total return is the sum of the income return and capital growth. The income return is the net income received by the owner, expressed as a percentage of the invested capital. Capital growth is the percentage of variation between the capital value at the end of the period and the amount originally invested. 
Figure 2. Share of foreign investors in the Central London across time: 2004-2015.
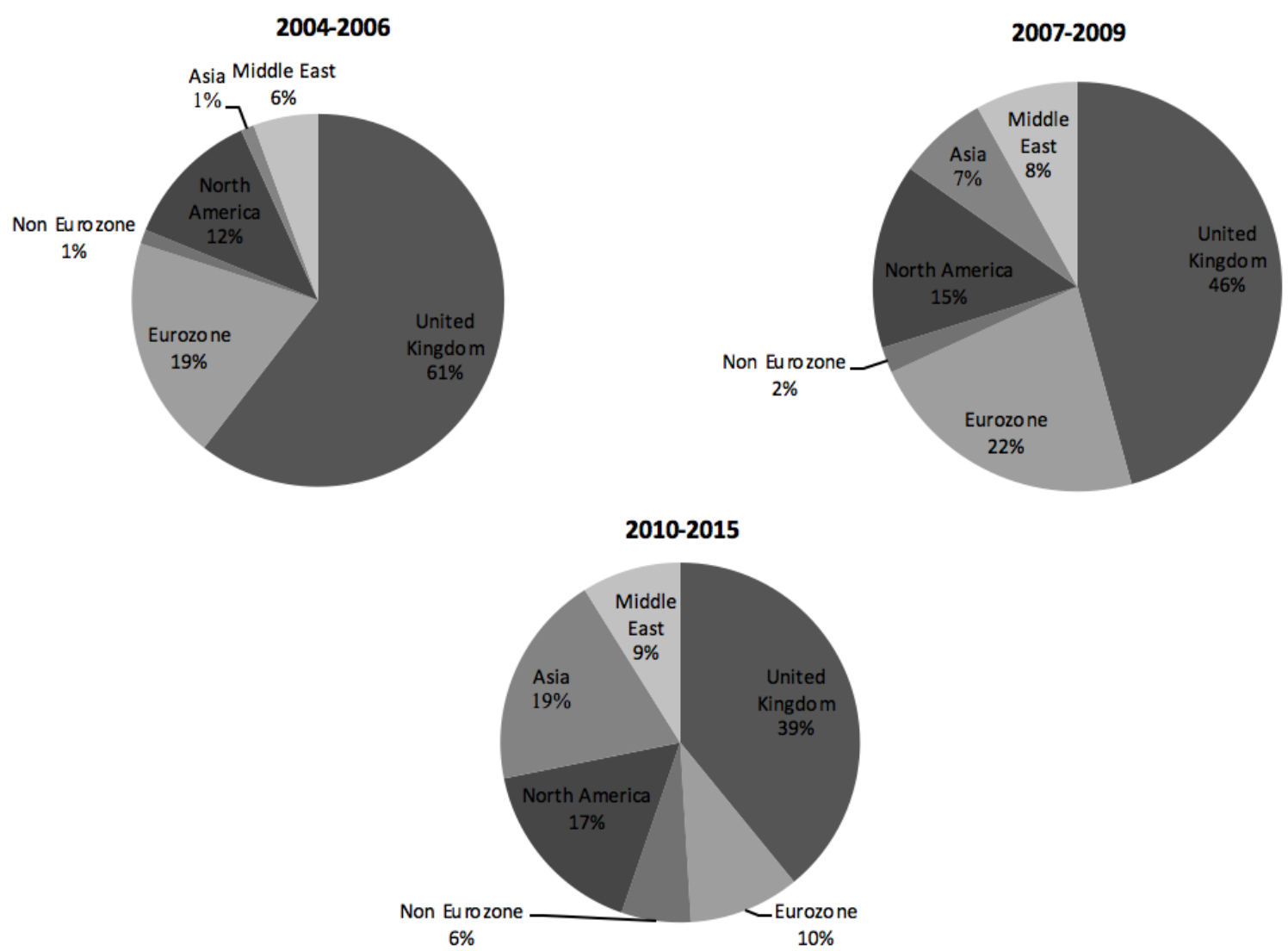

source: BNP Paribas Real Estate 
Figure 3. Breakpoints of the monetary index according to the Bai-Perron test: 2002-2005.

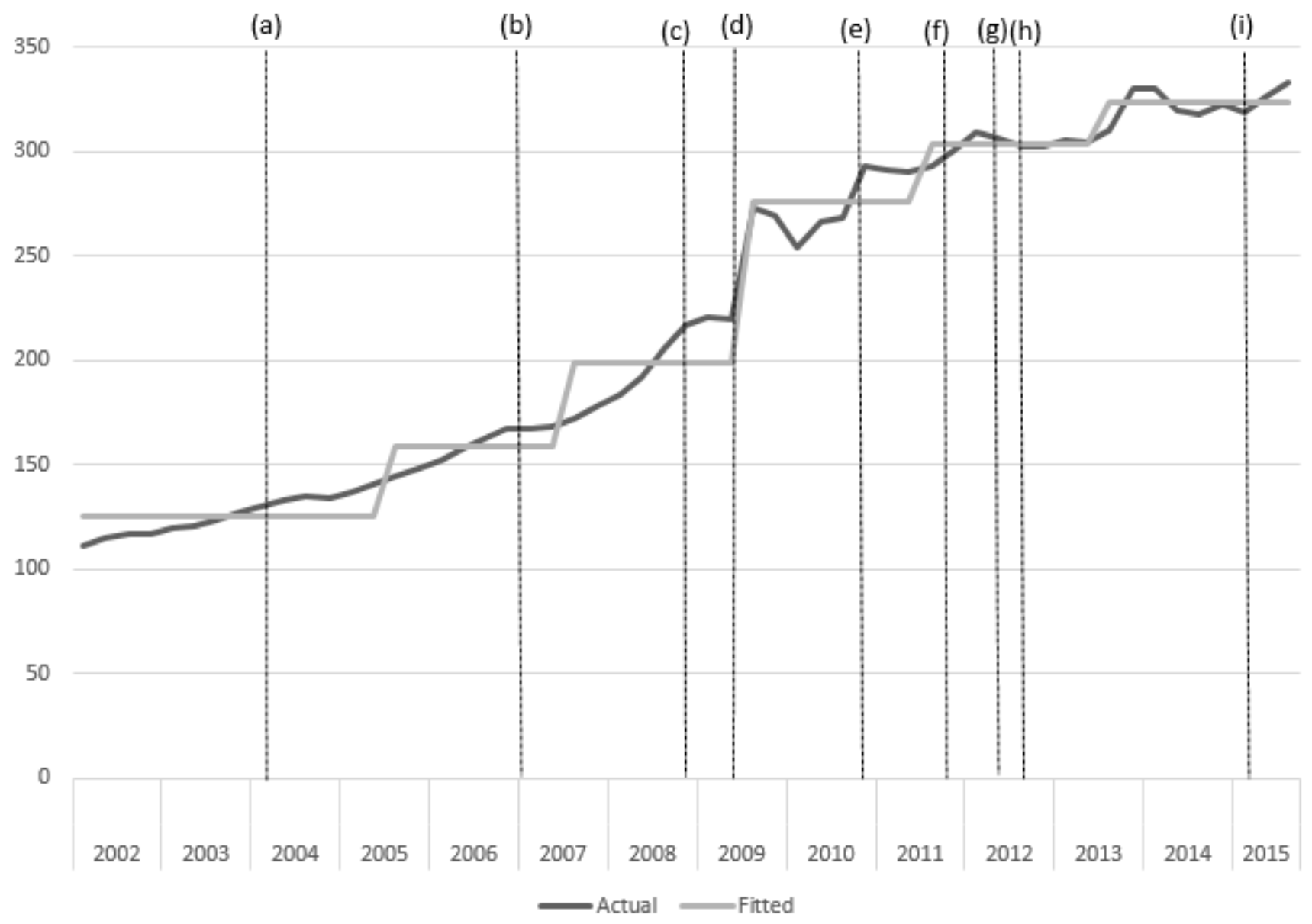

Notes: (a) Central banks begin to tighten their policy rates; (b) Beginning of the GFC; (c) Fed announces QE1; (d) Bank of England announces QE1; (e) Fed announces QE2; ( $f$ ) BoE announces QE3; ( $g$ ) Fed announces QE3; ( $h$ ) BoE announces QE3; (i) ECB announces QE. Sources: Bank of England and BNP Paribas Real Estate 
Figure 4. Impulse response functions following a shock in the monetary supply: 2002-2015.

Response to Structural One S.D. Innovations \pm 2 S.E.

Response of $\mathrm{D}(\mathrm{LOG}($ INDICE8)) to Shock

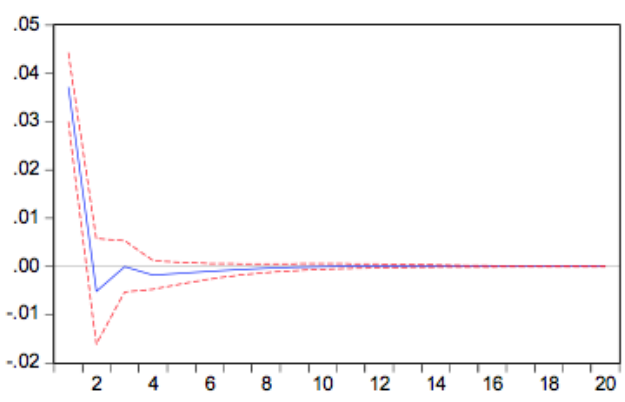

Response of D(LOG(EMPLOYEE_SERVICES)) to Shock1

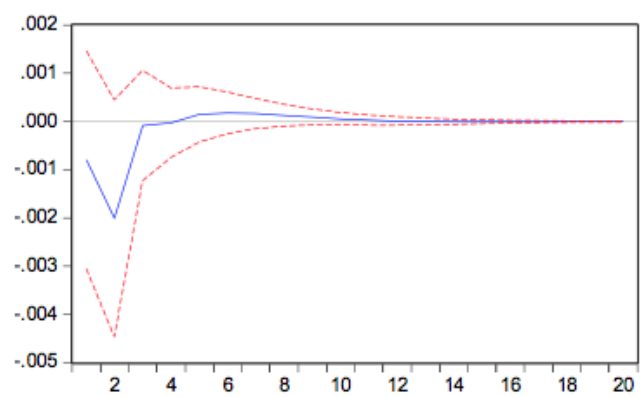

Response of D(LOG(PRIME_RENTAL_VALUE)) to Shock1

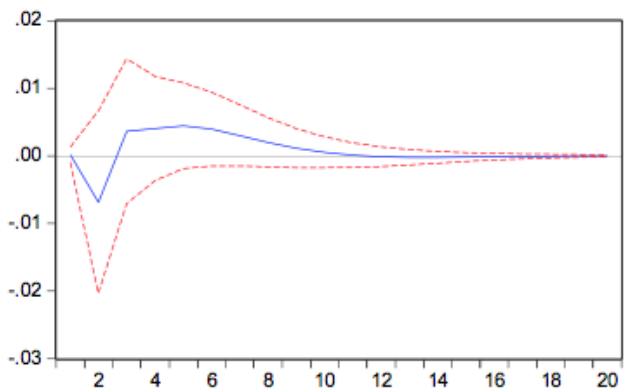

Response of D(LOG(FTSE_100_CLOSE_PRICE)) to Shock1

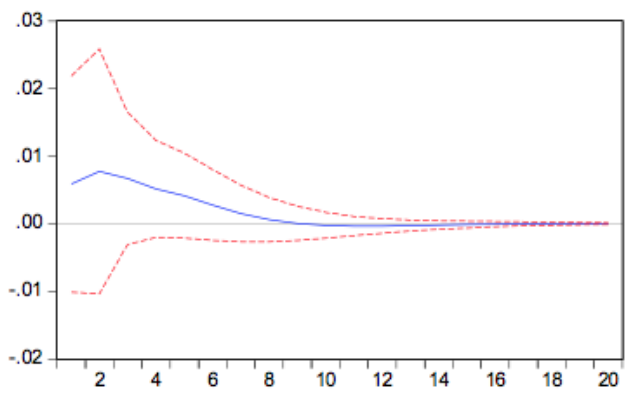

Response of D(LOG(VACANCY_RATE)) to Shock1

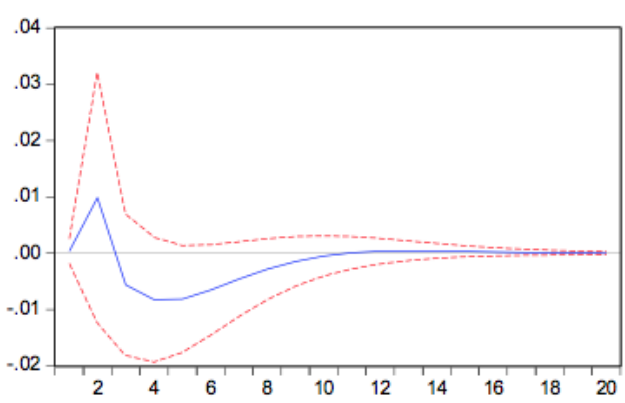

Response of D(PREMIUM_10_YEAR_GILT/100) to Shock1

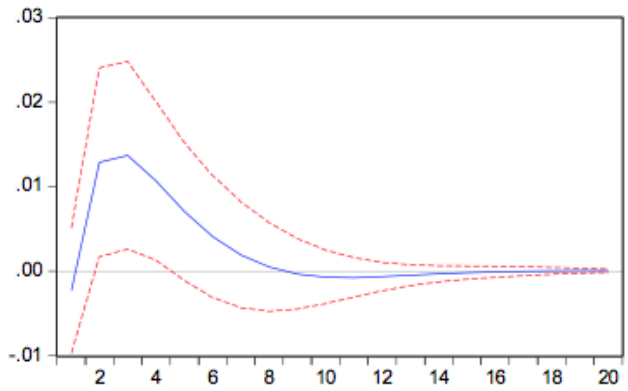

Notes: The responses are represented by solid lines. The dashed lines show the 95\% bootstrapped confidence intervals. The $x$-axis corresponds to the number of quarter following the shock. 
Table 1. Descriptive statistics of the variables in Central London: 2002-2015.

\begin{tabular}{|c|c|c|c|c|c|c|c|}
\hline & $\begin{array}{l}\text { Monetary } \\
\text { Index }\end{array}$ & $\begin{array}{l}\text { FTSE } \\
100\end{array}$ & Employment & $\begin{array}{l}\text { Vacancy } \\
\text { Rate }\end{array}$ & $\begin{array}{l}\text { Prime } \\
\text { Rent }\end{array}$ & $\begin{array}{l}\text { Risk } \\
\text { Pre- } \\
\text { mium }\end{array}$ & $\begin{array}{l}\text { Libor } \\
3- \\
\text { month }\end{array}$ \\
\hline & $\begin{array}{l}\text { Index }=100 \\
(2001-Q 1)\end{array}$ & & In thousand & $\%$ & $£$ & $\mathrm{pp}$ & $\%$ \\
\hline Mean & 213.25 & 5507.26 & 4444.566 & 7.61 & 996.36 & 6.38 & 2.96 \\
\hline Median & 191.76 & 5549.06 & 4431.345 & 7.38 & 969 & 9.37 & 3.8 \\
\hline Maximum & 332.54 & 6920.16 & 5190.887 & 11.65 & 1399 & 24.44 & 6.35 \\
\hline Minimum & 104.4 & 3695.69 & 4129.846 & 3.43 & 673 & -31.47 & 0.5 \\
\hline Std Dev & 81.84 & 862.65 & 307.4019 & 2.02 & 197.16 & 14.16 & 2.13 \\
\hline Skewness & 0.13 & -0.31 & 0.89927 & 0.15 & 0.21 & -1.09 & 0.01 \\
\hline Kurtosis & 1.36 & 2.09 & 2.770292 & 2.35 & 1.93 & 3.64 & 1.29 \\
\hline $\begin{array}{l}\text { Jarque- } \\
\text { Bera }\end{array}$ & 6.74 & 2.98 & 8.08 & 1.27 & 3.22 & 12.74 & 7.10 \\
\hline
\end{tabular}

Notes: "pp" refers to Percentage Points 


\begin{tabular}{|c|c|c|c|c|c|c|c|c|c|c|c|c|c|}
\hline 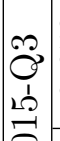 & $\begin{array}{ll}0 & 0 \\
0 & 8 \\
0 & 0 \\
0 & 10 \\
\end{array}$ & 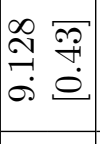 & 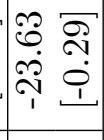 & 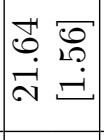 & 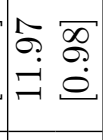 & & 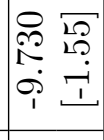 & 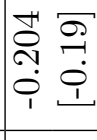 & $\begin{array}{l}\infty \\
1 \\
0 \\
0\end{array}$ & $\stackrel{1}{0}$ & $\ddot{\circ}$ & $\begin{array}{l}0 \\
10 \\
0 \\
1\end{array}$ & \\
\hline $\begin{array}{l}0 \\
N \\
0 \\
\pm \\
0 \\
0\end{array}$ & $\begin{array}{ll}\vec{\sigma} & \bar{N} \\
0 & \mathbb{N} \\
0 & 0 \\
0\end{array}$ & $\mid$\begin{tabular}{ll}
2 & 0 \\
2 & 0 \\
0 & 0 \\
0 & 0 \\
\hdashline & 1 \\
1 & 1 \\
\end{tabular} & 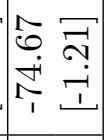 & 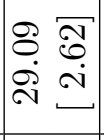 & 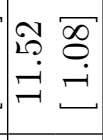 & 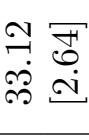 & & 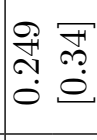 & $\begin{array}{c}-1 \\
0 \\
0\end{array}$ & 是 & $\begin{array}{l}\vec{N} \\
i s\end{array}$ & \begin{tabular}{l}
$\overrightarrow{7}$ \\
\hdashline 0 \\
0 \\
1
\end{tabular} & 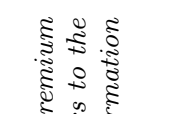 \\
\hline 悹 & $\begin{array}{ll}10 & 0 \\
0 & 0 \\
0 & 0 \\
0 & \dot{0} \\
0 & 2\end{array}$ & $\begin{array}{ll}\vec{b} & \\
0 & 0 \\
0 & 0 \\
0 & 0 \\
1 & 1 \\
1 & 1\end{array}$ & 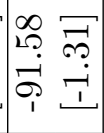 & 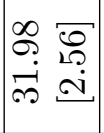 & 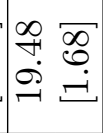 & & & 동 & $\begin{array}{l}100 \\
\stackrel{1}{0} \\
0\end{array}$ & : & $\begin{array}{l}7 \\
10\end{array}$ & $\mid \begin{array}{l}10 \\
1 \\
0 \\
1 \\
1\end{array}$ & 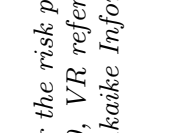 \\
\hline $\begin{array}{c}1 \\
0 \\
1 \\
\infty \\
0 \\
0\end{array}$ & 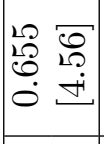 & 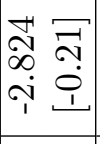 & 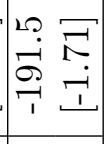 & 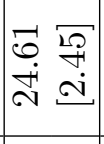 & 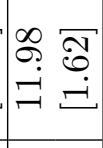 & & 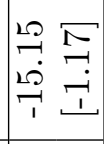 & $\mid$\begin{tabular}{ll}
1 & $\infty$ \\
$\infty$ & $\infty$ \\
\hdashline & 0 \\
\hdashline & 0 \\
0 & 0
\end{tabular} & $\ddot{0}$ & Oै. & $\begin{array}{l}\infty \\
0 \\
10 \\
10\end{array}$ & $\begin{array}{l}0 \\
\dot{0} \\
\end{array}$ & 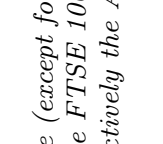 \\
\hline $\begin{array}{l}\tilde{N} \\
0 \\
\dot{1} \\
\tilde{O} \\
\end{array}$ & 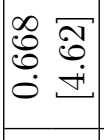 & 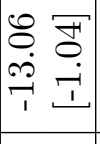 & \begin{tabular}{ll}
1 & \multicolumn{1}{c}{} \\
$\infty$ & 0 \\
0 & 0 \\
\hdashline & - \\
1 & -
\end{tabular} & 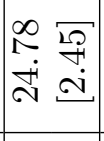 & 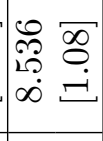 & 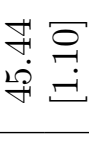 & & $\begin{array}{ll}\tilde{N} & \overline{0} \\
0 & 0 \\
0 & 0 \\
1 & 1 \\
1\end{array}$ & $\ddot{0}$ & : & $\begin{array}{l}\infty \\
0 \\
0 \\
10 .\end{array}$ & 権 & 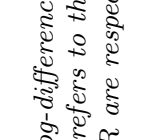 \\
\hline 尺े & 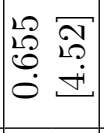 & 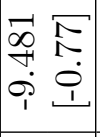 & 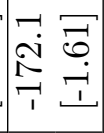 & 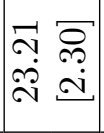 & 番 & & & 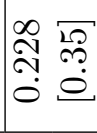 & O̊ & $\ddot{0}$ & ڤ. & $\begin{array}{l}10 \\
\text { îं } \\
1 \\
1\end{array}$ & 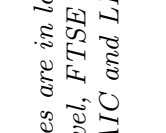 \\
\hline 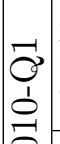 & 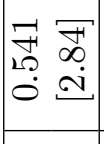 & 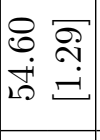 & 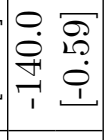 & 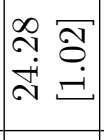 & 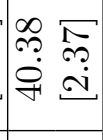 & & 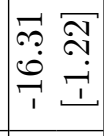 & 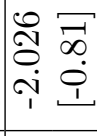 & $\ddot{0}$ & - & न & 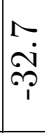 & 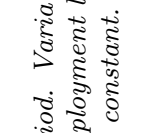 \\
\hline$\left|\begin{array}{c}\tilde{N} \\
0 \\
+ \\
-1 \\
\sigma\end{array}\right|$ & 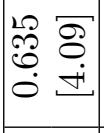 & 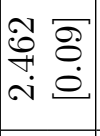 & 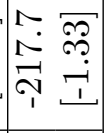 & 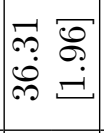 & 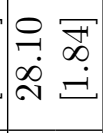 & 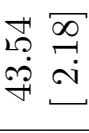 & & \begin{tabular}{ll}
$R$ & 0 \\
0 & $\infty$ \\
\hdashline & $\dot{0}$ \\
1 & 1 \\
\end{tabular} & m & 㐌 & $\begin{array}{l}\mathbb{N} \\
20 \\
20\end{array}$ & 每 & 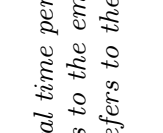 \\
\hline 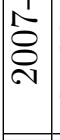 & 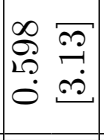 & $\mid$\begin{tabular}{cc}
2 & 0 \\
$\infty$ & 0 \\
0 & 0 \\
0 & 0 \\
\hdashline & 0 \\
\end{tabular} & 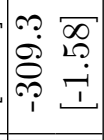 & 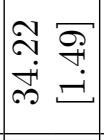 & 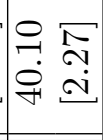 & & & 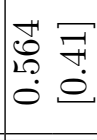 & $\begin{array}{l}\infty \\
\infty \\
0 \\
0\end{array}$ & $\infty$ & ㄱ. & Pُ & 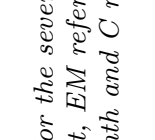 \\
\hline $\begin{array}{l}-1 \\
0 \\
0 \\
0 \\
0\end{array}$ & 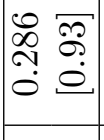 & 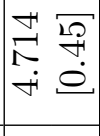 & 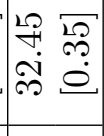 & 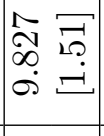 & 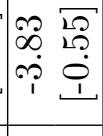 & & 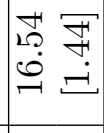 & 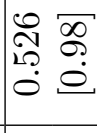 & $\begin{array}{l}\infty \\
0 \\
0 \\
0\end{array}$ & (2) & 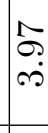 & 傗 & 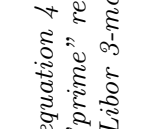 \\
\hline$\left|\begin{array}{c}\tilde{N} \\
\infty \\
+ \\
\tilde{O} \\
\sigma\end{array}\right|$ & 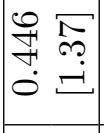 & 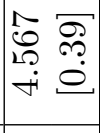 & \begin{tabular}{ll}
0 & $\infty$ \\
$\infty$ & 0 \\
$\infty$ & 0 \\
\hdashline & 0 \\
1 & 1
\end{tabular} & 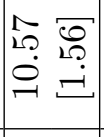 & 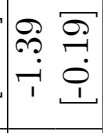 & 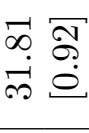 & & $\begin{array}{ll}1 & \bar{F} \\
0 & 0 \\
0 & 0 \\
0 & 0 \\
1 & 1\end{array}$ & 迥 & 苛 & $\stackrel{8}{\stackrel{\leftrightarrow}{+}}$ & 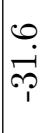 & $\begin{array}{l}0 \\
\text { हैँ }\end{array}$ \\
\hline 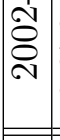 & 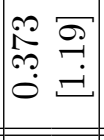 & 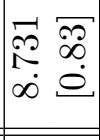 & 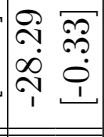 & 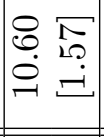 & 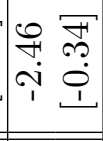 & & & 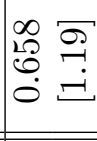 & ڤ్ & Fे & $\stackrel{\mathscr{I}}{\stackrel{\sim}{\rightarrow}}$ & 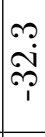 & 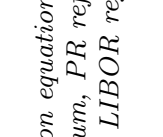 \\
\hline 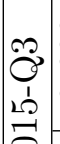 & 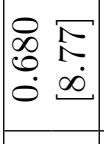 & $\begin{array}{ll}\infty & 0 \\
\infty & 0 \\
\infty & 0 \\
0 & 0 \\
0 & 0\end{array}$ & 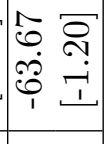 & 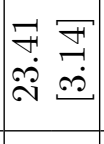 & 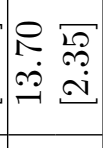 & & 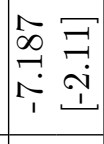 & 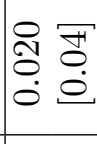 & $\begin{array}{l}0 \\
1 \\
0\end{array}$ & î & $\begin{array}{l}29 \\
0 \\
20\end{array}$ & 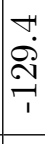 & $\begin{array}{l}8 \\
0 \\
1\end{array}$ \\
\hline $\begin{array}{c}\tilde{N} \\
o \\
\stackrel{1}{2} \\
\stackrel{\sigma}{\sigma}\end{array} \mid$ & 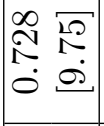 & 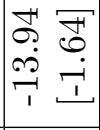 & 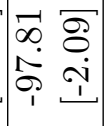 & $\left|\begin{array}{ll}\overrightarrow{0} & \overline{0} \\
\dot{0} & \infty \\
\stackrel{0}{0} & \dot{0}\end{array}\right|$ & 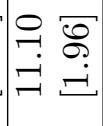 & 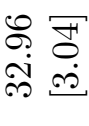 & & 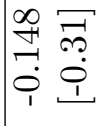 & 年 & 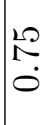 & 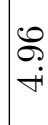 & N & \\
\hline 宊 & $\begin{array}{ll}\overrightarrow{1} & \infty \\
0 & 0 \\
0 & 0 \\
0 & 0 \\
0 & 0\end{array}$ & 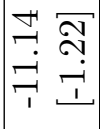 & $\begin{array}{ll}1 & \overline{7} \\
\dot{8} & \overrightarrow{7} \\
\vec{i} & \stackrel{1}{1}\end{array}$ & 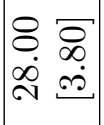 & 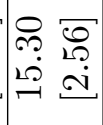 & & & 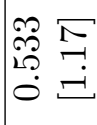 & $\stackrel{\Re}{\stackrel{2}{0}}$ & R & $=$ & 5 & \\
\hline & مि & $\frac{w}{2}$ & $\sum_{\mid \underline{I}}$ & ED & $\stackrel{2}{s}$ & 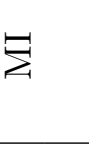 & 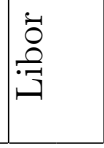 & U & st & $\overline{4}$ & $\overline{4}$ & & \\
\hline
\end{tabular}




\section{AppendixA. Stationarity of the variables.}

\begin{tabular}{|c|c|c|c|c|}
\hline Variable (level) & ADF t-Statistic & PP t-Statistic & Prob. ADF & Prob. PP \\
\hline Risk Premium & $-4.297551^{* * *}$ & -2.291927 & 0.0011 & 0.1780 \\
Prime Rent & -1.488341 & -1.102262 & 0.5323 & 0.7093 \\
Employment level & -1.189591 & -1.471519 & 0.6733 & 0.5409 \\
FTSE 100 & -1.955773 & -1.711095 & 0.3052 & 0.4204 \\
Vacancy Rate & -2.427356 & -2.442641 & 0.1390 & 0.1349 \\
LIBOR 3 Month & -1.443086 & -1.289566 & 0.5549 & 0.6287 \\
Monetary Index & -0.299007 & -0.270200 & 0.9182 & 0.9225 \\
\hline \hline Variable (1st difference) & ADF t-Statistic & PP t-Statistic & Prob. ADF & Prob. PP \\
\hline Risk Premium & $-3.711170^{* * *}$ & $-3.078110^{* * *}$ & 0.0064 & 0.0339 \\
Prime Rent & $-3.919561^{* * *}$ & $-3.905711^{* * *}$ & 0.0035 & 0.0036 \\
Employment level & $-6.451485^{* * *}$ & $-6.388660^{* * *}$ & 0.0000 & 0.0000 \\
FTSE 100 & $-5.284743^{* * *}$ & $-5.278236^{* * *}$ & 0.0000 & 0.0000 \\
Vacancy Rate & $-4.277398^{* * *}$ & $-4.301653^{* * *}$ & 0.0012 & 0.0011 \\
LIBOR 3 Month & $-3.955824^{* * *}$ & $-3.937701^{* * *}$ & 0.0031 & 0.0033 \\
Monetary Index & $-7.180174^{* * *}$ & $-7.192899^{* * *}$ & 0.0000 & 0.0000 \\
\hline
\end{tabular}

Notes: T-statistics are in brackets. *, **, *** indicates significant at 10\%, 5\% and $1 \%$ respectively. ADF and PP are respectively the Augmented Dickey Fuller and the Phillips-Perron unit root tests. 


\section{AppendixB. Optimal lag length for the monetary index}

\begin{tabular}{|c|c|c|c|c|c|}
\hline & No Lag & 1 Lag & 2 Lags & 3 Lags & 4 Lags \\
\hline RP & 0.69 & 0.66 & 0.68 & 0.73 & 0.7 \\
& {$[8.57]$} & {$[8.59]$} & {$[8.58]$} & {$[9.75]$} & {$[8.80]$} \\
\hline PR & -11.16 & -19.86 & -12.20 & -13.94 & -9.55 \\
& {$[-1.21]$} & {$[-2.10]$} & {$[-1.34]$} & {$[-1.64]$} & {$[-1.04]$} \\
\hline EM & -108.65 & -135.12 & -104.35 & -97.81 & -82.71 \\
& {$[-2.13]$} & {$[-2.71]$} & {$[-2.08]$} & {$[-2.09]$} & {$[-1.55]$} \\
\hline FTSE & 29.05 & 28.21 & 28.78 & 26.01 & 26.71 \\
& {$[3.77]$} & {$[4.01]$} & {$[3.91]$} & {$[3.80]$} & {$[3.62]$} \\
\hline VR & 15.49 & 12.23 & 16.44 & 11.10 & 14.62 \\
& {$[2.57]$} & {$[2.29]$} & {$[2.74]$} & {$[1.95]$} & {$[2.46]$} \\
\hline MI & 8.39 & -27.67 & -21.12 & 32.96 & 21.60 \\
& {$[0.51]$} & {$[-2.38]$} & {$[-1.12]$} & {$[3.04]$} & {$[1.30]$} \\
\hline C & 0.37 & 1.35 & 0.99 & -0.15 & -0.015 \\
& {$[0.69]$} & {$[2.45]$} & {$[1.72]$} & {$[-0.31]$} & {$[-0.02]$} \\
\hline \hline R $^{2}$ & 0.73 & 0.76 & 0.74 & 0.77 & 0.74 \\
\hline Adj-R & 0.70 & 0.73 & 0.71 & 0.75 & 0.71 \\
\hline AIC & 5.14 & 5.03 & 5.11 & 4.96 & 5.10 \\
\hline LR & -131.8 & -128.8 & $-131,0$ & -127.04 & $-130,9$ \\
\hline
\end{tabular}

Notes: Appendix $B$ reports regression results based on equation 4 for the whole period with different time-lags for the monetary index. Variables are in log-difference (except for the risk premium in first-difference). RP refers to the risk premium, PR refers to the "prime" rent, EM refers to the employment level, FTSE refers to the FTSE 100 , VR refers to the vacancy rate, $M I$ refers to the monetary index, LIBOR refers to the Libor 3-month and $C$ refers to the constant. AIC and LR are respectively the Akaike Information Criteria and the Likelihood Ratio.

T-statistics are in brackets. 
AppendixC. Impulse Response Functions following a positive one standard devi-
ation shock to the monetary index after QE programs: 2009-2015.

Response to Structural One S.D. Innovations \pm 2 S.E.

Response of $\mathrm{D}(\mathrm{LOG}(\mathrm{INDICEB}))$ to Shock1

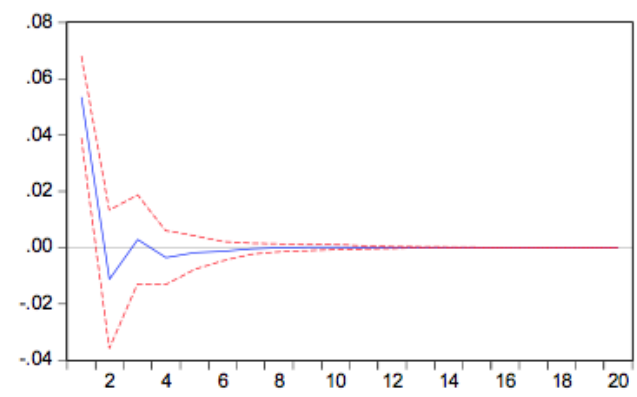

Response of D(LOG(EMPLOYEE_SERVICES)) to Shock1

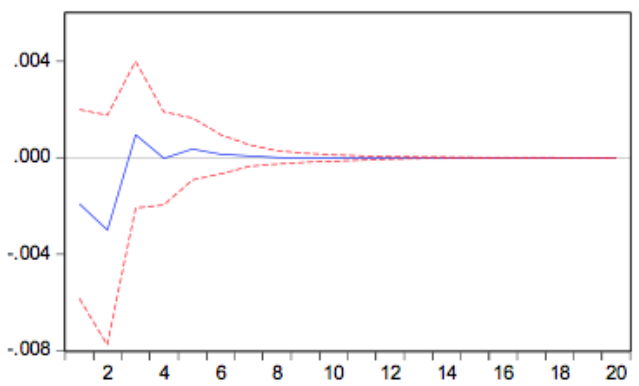

Response of D(LOG(PRIME_RENTAL_VALUE)) to Shock1

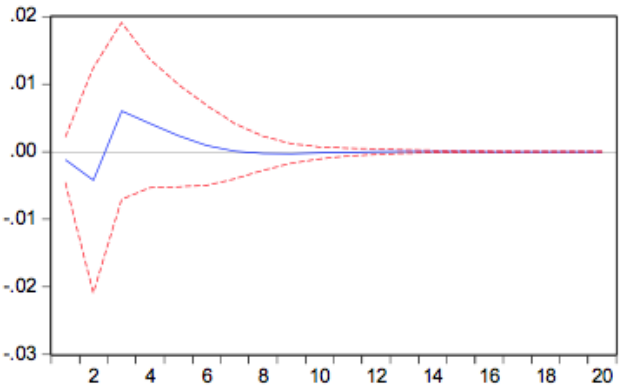

Response of D(LOG(FTSE_100_CLOSE_PRICE)) to Shock1

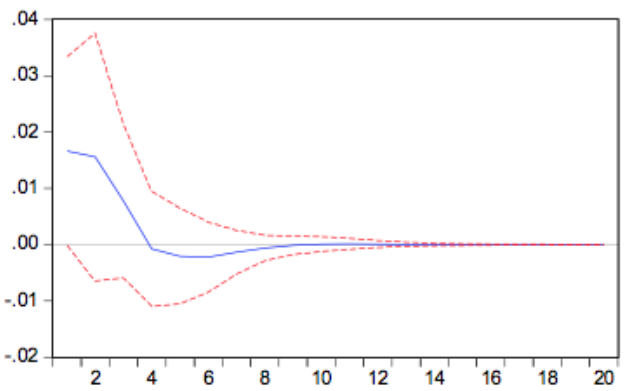

Response of D(LOG(VACANCY_RATE)) to Shock1

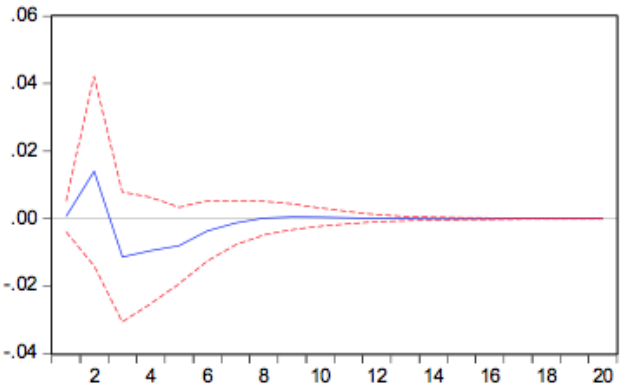

Response of D(PREMIUM_10_YEAR_GILT/100) to Shock1

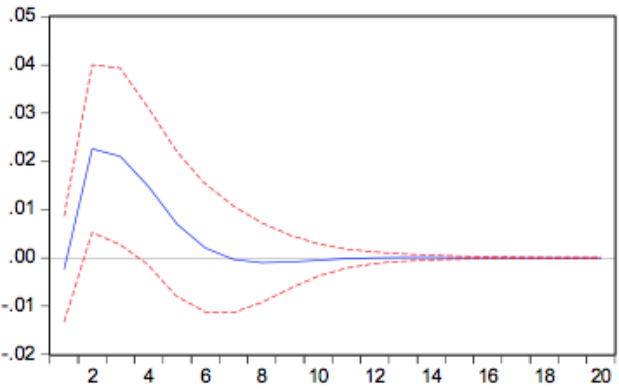

Notes: The responses are represented by solid lines. The dashed lines show the $95 \%$ bootstrapped confidence intervals. The $x$-axis corresponds to the number of quarter following the shock 
AppendixD. Impulse Response Functions following a positive one standard deviation shock to the 3-month Libor rate: 2002-2015

Response to Structural One S.D. Innovations \pm 2 S.E.

Response of D(LOG(LIBOR_3M)) to Shock1

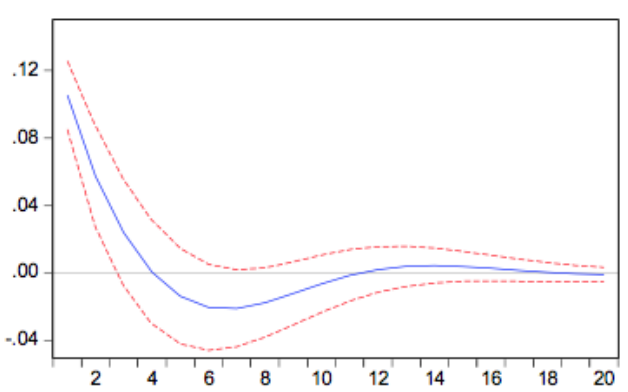

Response of D(LOG(EMPLOYEE_SERVICES)) to Shock1

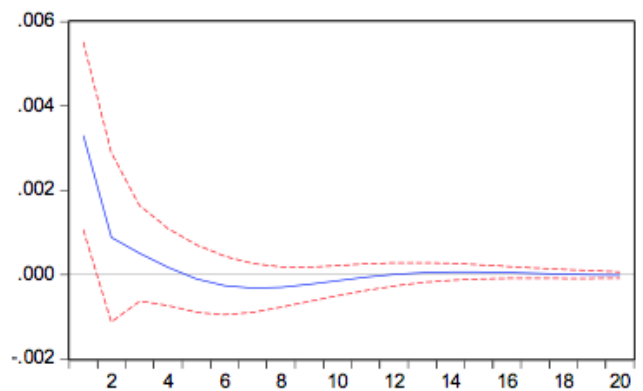

Response of D(LOG(PRIME_RENTAL_VALUE)) to Shock1

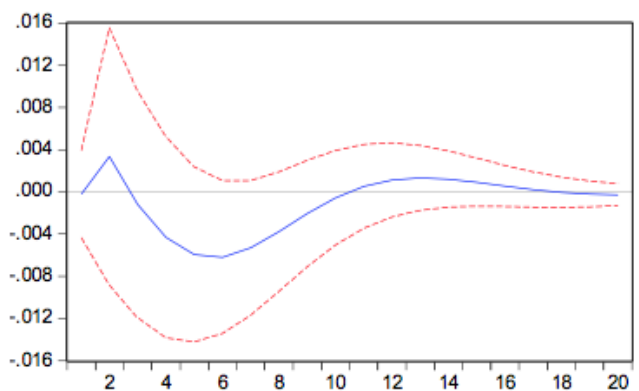

Response of D(LOG(FTSE_100_CLOSE_PRICE)) to Shock1

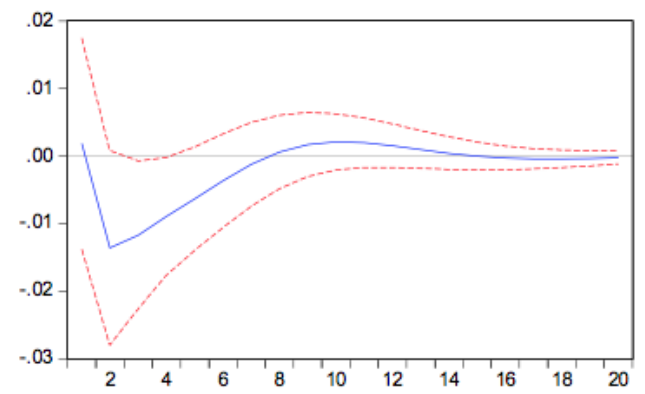

Response of D(LOG(VACANCY_RATE)) to Shock1

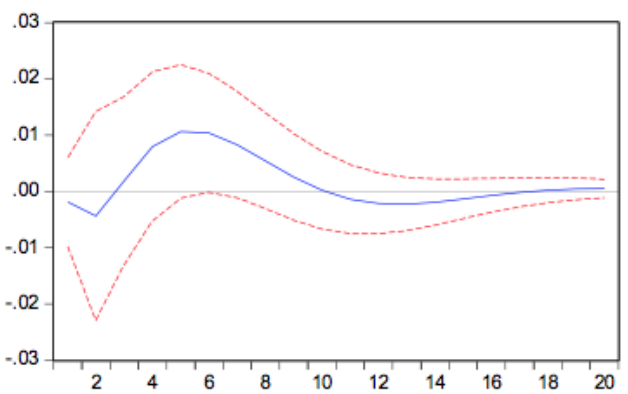

Response of D(PREMIUM_10_YEAR_GILT/100) to Shock1

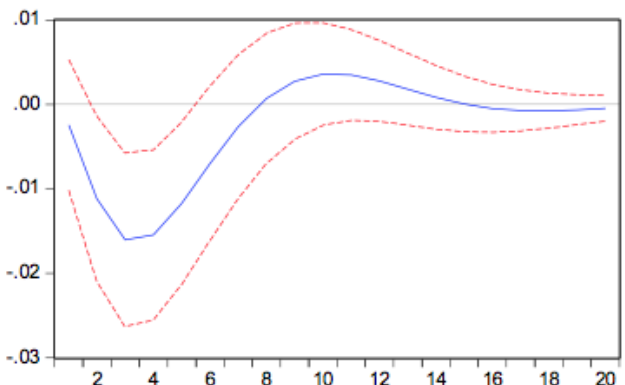

Notes: The responses are represented by solid lines. The dashed lines show the $95 \%$ bootstrapped confidence intervals. The $x$-axis corresponds to the number of quarter following the shock 